\title{
Comparison of the neutralization sensitivity of South African and Indian HIV-1 subtype C viruses to South African plasma antibodies
}

\author{
T Hermanus $^{1 *}$, N Mkhize ${ }^{1}$, P Moore ${ }^{1}$, M Nonyane ${ }^{1}$, J Battacharya ${ }^{2}$, SA Karim ${ }^{3}$ L L Morris \\ From AIDS Vaccine 2012 \\ Boston, MA, USA. 9-12 September 2012
}

\section{Background}

HIV-1 subtype $C$ is the predominant subtype in India and South Africa (SA) responsible for explosive epidemics. An understanding of the neutralization sensitivity of viruses from these regions will help to define shared epitopes in the envelope protein, which may be important for inclusion in an effective subtype $\mathrm{C}$-specific vaccine.

\section{Methods}

Plasma from 44 chronically HIV-1 subtype $\mathrm{C}$ infected SA individuals in the CAPRISA 002 Acute Infection cohort were used to assess the neutralization sensitivity of 10 SA and 9 Indian Tier 2 viruses in a TZM-bl assay. Intra-subtype neutralization activity between SA and Indian viruses was determined. The envelope sequence of the Indian panel was analyzed in order to identify epitopes known to be targeted by the neutralizing antibodies in a subset of the CAPRISA plasmas.

\section{Results}

South African and Indian viruses were generally sensitive to the most potent plasmas. However, SA viruses showed overall greater sensitivity compared to Indian viruses; neutralization of $50 \%$ of the SA virus panel was achieved by $15 / 44$ (34\%) of the plasmas compared to only $6 / 44(14 \%)$ against the Indian panel. Furthermore, neutralization titers against SA viruses were higher, with 9/44 (21\%) of plasmas neutralizing at $>1: 200$ compared to 5/44 (11\%) against the Indian panel. An analysis of the gp160 sequences suggested that genetic differences in key neutralization epitopes between SA and Indian viruses were in part responsible for differences in sensitivity.

${ }^{1}$ National Institute for Communicable Diseases, Johannesburg, South Africa Full list of author information is available at the end of the article

\section{Conclusion}

These data suggest the presence of common neutralization epitopes between SA and Indian viruses although there is also evidence for regional neutralization determinants within subtype $C$. The finding that SA viruses were generally neutralized at higher titers, suggests that the exposure of common epitopes on envelope may vary between SA and Indian viruses. Overall, these data support the development of a subtype $\mathrm{C}$-specific vaccine that can be used in both SA and India.

\section{Author details}

${ }^{1}$ National Institute for Communicable Diseases, Johannesburg, South Africa. ${ }^{2}$ National AIDS Research Institute, Pune, India. ${ }^{3}$ Center for AIDS Program of Research in South Africa, Durban, South Africa.

Published: 13 September 2012

doi:10.1186/1742-4690-9-S2-P66

Cite this article as: Hermanus et al:: Comparison of the neutralization sensitivity of South African and Indian HIV-1 subtype C viruses to South African plasma antibodies. Retrovirology 2012 9(Suppl 2):P66.

Submit your next manuscript to BioMed Central and take full advantage of:

- Convenient online submission

- Thorough peer review

- No space constraints or color figure charges

- Immediate publication on acceptance

- Inclusion in PubMed, CAS, Scopus and Google Scholar

- Research which is freely available for redistribution

\section{(Ciomed Central}

